SHARP và AP cho thây, hiệu quả của sorafenib dường như kém hơn ở nhóm bệnh nhân VGB. Trong nghiên cứu SHARP VGC (28\%), chỉ khoảng $18 \%$ bệnh nhân VGB. Tuy nhiên trong nghiên cứu $A P, 71 \%$ và $78 \%$ bệnh nhân ở nhóm điều trị sorafenib và nhóm chứng nhiễm VGB. Thời gian sống trung vị ở nghiên cứu $A P$ là 7,8 tháng thấp hơn so với nghiên cứu SHARP là 10,7 tháng. Trong một số nghiên cứu khác, phân tích sâu cũng cho thấy hiệu quả sorafenib ở nhóm viêm gan virus $C$ hoặc không bị nhiễm viêm gan virus $B$ cao hơn $(10,2$ tháng và 12,6 tháng so với các nhóm khác) [1], [2]. Tại Việt Nam, cho đến nay chưa có nghiên cứu nào đỉ sâu phân tích ảnh hưởng của nhiễm viêm gan virus tới kết quả điêu trị của thuốc, đa số đánh giá hiệu quả chung của sorafenib trên tất cả các đối tượng điêuu trị, do vậy chúng tôi không so sánh được kết quá trên với các nghiên cứu trong nước.

\section{KẾT LUẬN}

Viêm gan virus $B$ cho kết quả điều trị thấp hơn về tỷ lệ kiểm soát bệnh, thời gian sống bệnh không tiến triển và thời gian sống toàn bộ so với không nhiễm viêm gan virus $B$. Nhiễm viêm gan virus $B$ là yếu tố tiên lượng độc lập đến kết quả điêu trị của sorafenib trên bệnh nhân ung thư biểu mô tế bào gan. Nhiễm viếm gan virus $B$ làm tăng gấp 2,5 lân nguy cơ tử vong so với không viêm gan virus.

Lời cảm ơn: Chúng tôi xin trân trọng cảm ơn Ban lãnh đạo, Phòng Kế hoạch tổng hợp, các khoa lâm sàng Bệnh viện K, Bệnh viện Đại học Y
Hà Nội đã tạo mọi điêuu kiện giúp tôi hoàn thành nghiên cứu này.

\section{TÀI LIÊU THAM KHẢO}

1. Cheng A L, Kang Y K, Chen Z, et al (2009). Efficacy and safety of sorafenib in patients in the Asia-Pacific region with advanced hepatocellular carcinoma: a phase III randomised, double-blind, placebo-controlled trial. Lancet Oncol, 10(1), 25-34.

2. Llovet J.M, Ricci S, Mazzaferro V, et al (2008). Sorafenib in Advanced Hepatocellular Carcinoma. New England Journal of Medicine, 359(4), 378-390.

3. Bruix J, Cheng AL, Meinhardt G et al (2017) Prognostic factors and predictors of sorafenib benefit in patients with hepatocellular carcinoma: Analysis of two phase III studies. J Hepatol, 67(5), 999-1008.

4. Bray F, Ferlay J, Soerjomataram I, et al (2018). Global cancer statistics 2018: GLOBOCAN estimates of incidence and mortality worldwide for 36 cancers in 185 countries. CA Cancer J Clin, 68(6), 394-424.

5. Bộ Y tế Việt Nam (2012). Hướng dẫn chẩn đoán và điều trị ung thư tế bào gan nguyên phát. Quyết định số 5250/QĐ-BYT.

6. Pressiani T, Boni C, Rimassa L et al (2013). Sorafenib in patients with Child-Pugh class A and B advanced hepatocellular carcinoma: aprospective feasibility analysis. Ann Oncol, 24(2), 406-411.

7. Nakano M, Tanaka $M$, Kuromatsu $R$ et al (2015). Sorafenib for the treatment of advanced hepatocellular carcinoma with extrahepatic metastasis: a prospective multicenter cohort study. Cancer Med, 4(12), 1836-1843.

8. Di Costanzo GG, Sacco R, de Stefano G et al (2015). Safety and efficacyof sorafenib in STELLA study, a multicenter, observational, phase IV study in Italian centers [abstract no. L17]. Ann Oncol, 26(6).

\title{
XÁC ĐİNH ĐộT BIẾN GEN CDH1 TRÊN BÊNHH NHÂN UNG THƯ DẠ DÀY LAN TOẢ Ở VIẾT NAM
}

\author{
Vũ Trường Khanh ${ }^{1}$, Nguyễn Quý Linh ${ }^{2}$, Vũ Hải Linh ${ }^{3}$, \\ Đào Trần Tiến ${ }^{1}$, Trần Vân Khánh ${ }^{2}$, Trần Huy Thịnh ${ }^{1}$
}

\section{TÓM TẮT}

Ung thư dạ dày là một trong năm loại ung thư phổ biến nhất trên thế giới. Theo phân loại của Lauren, ung thư dạ dày type lan toả là một trong ba thể ung

\footnotetext{
${ }^{1}$ Trường Đại học Y Hà Nội

${ }^{2}$ Bệnh viện Bạch Mai

${ }^{3}$ Bệnh viện $K$

Chịu trách nhiệm chính: Trân Huy Thịnh

Email: tranhuythinh@hmu.edu.vn

Ngày nhận bài: 23.2.2021

Ngày phản biện khoa học: 29.3.2021

Ngày duyệt bài: 8.1.2021
}

thư dạ dày, được đặc trưng bởi sự biệt hoá kém, khả năng xâm lấn và di căn cao. $\mathrm{CDH} 1$ là gen mã hoá cho protein E-cadherin, đóng vai trò quan trong trong kết dính tế bào và duy trì tính toàn vẹn biểu mô. Chính vì những chức năng quan trọng này mà đột biến gen $\mathrm{CDH} 1$ làm tăng nguy cơ gây ung thư dạ dày. Đột biến gen $\mathrm{CDH} 1$ được được chứng minh là một trong những cơ chế phân tử chính gây ung thư dạ dày type lan toả. Chúng tôi tiến hành giải trình tự toàn bộ gen $\mathrm{CDH} 1$ của 30 bệnh nhân được chẩn đoán ung thư dạ dày type lan toả. Kết quả xác định được 15/30 bệnh nhân mang đột biến gen $\mathrm{CDH} 1$. Trong đó, các đột biến phổ biến nhẩt phát hiên được là đột biến tại vùng intron 1 $c 48+6 \mathrm{C}>\mathrm{T}$, chiếm $33.3 \%$ tổng số ca bệnh phát hiện đột biến; tiếp đến là đột biến tại operator c1-285 C > 
A và đột biến tại exon 8 c.1248 delT, đều chiếm $20 \%$. Tứ khoá: Üng thư da dày type lan toả, đột biến, gen $\mathrm{CDH} 1$

\section{SUMMARY}

IDENTIFICATION OF CDH1 MUTATION IN DIFFUSE GASTRIC CANCER PATIENTS

Gastric cancer is one of five most common types of cancer worldwide. According to the Lauren classification, diffuse gastric cancer is one of three types of gastric cancer. It is characterized by poor differentiation with highly invasive and metastatic probability. The $\mathrm{CDH} 1$ gene encodes for the $\mathrm{E}$ cadherin protein and plays an important role in cellcell adhesion and maintenance of epithelial integrity. Because of these important functions, a $\mathrm{CDH} 1$ gene mutation increases the risk of gastric cancer. $\mathrm{CDH} 1$ gene mutations have been shown to be one of two molecular mechanisms responsible for diffuse gastric cancer. We performed genetic sequencing $\mathrm{CDH} 1$ gene of 30 patients that was diagnosis as diffuse gastric cancer. The results show that $15 / 30$ patients had a mutation of $\mathrm{CDH} 1$ gene. Among of these, mutation in intron $1 \mathrm{c} 48+6 \mathrm{C}>\mathrm{T}$ is the most popular $(33.3 \%)$, next is mutation in operator c1-285 C > A and in exon 8 c.1248 delT (20\%).

Keywords: Diffuse gastric cancer, mutation, $\mathrm{CDH} 1$

\section{I. ĐĂT VẤN ĐỀ}

Ung thư hiên nay là vấn đề chăm sóc sức khoẻ được quan tâm trên góc độ toàn câu. Trong các loại ung thư hiện nay, ung thư dạ dày là loại ung thư phổ biến và chiếm tỷ lệ tử vong cao. Theo GLOBOCAN 2020, ung thư da dày đứng thứ năm trong các bệnh ung thư phổ biến và đứng thứ ba về số ca tử vong [1]. Hơn $70 \%$ số ca ung thư da dày xảy ra ở các nước đang phát triển, trong đó $50 \%$ trường hợp xảy ra ở Đông Á [2]. Đa số ung thư dạ dày thuộc loại ung thư biểu mô (tuyến) nên P. Lauren (1965) đã chia ung thư dạ dày thành ba loại theo hệ thống D.I.O bao gồm ung thư biểu mô type lan toả, ung thư biểu mô type ruột và các dạng ung thư biểu mô còn lại. Trong đó, ung thư biểu mô type lan toả thường mang tính di truyền, chiếm 1-3\% số ca ung thư dạ dày.

Ung thư da dày di truyền được biết đến do những biến đổi bất thường ở mức độ gen với đặc trưng là khởi phát sớm, di truyền đa thế hệ và có khả năng di căn cao [3]. Hơn 20 gen khác nhau được phát hiện có liên quan đến ung thư dạ dày di truyền. Trong đó, đột biến gen $\mathrm{CDH} 1$ được chú ý đến do chiếm khoảng $40 \%$ trường hợp ung thư dạ dày lan toả di truyền [4]. Gen CDH1 mã hoá cho glycoprotein E-cadherin, có vai trò quan trọng trong việc kết dính tế bào, duy trì hình thái biểu mô, cân bằng nội môi và tham gia các con đường truyền tín hiệu tế bào
[3]. Khi gen $\mathrm{CDH} 1$ xảy ra đột biến, protein $\mathrm{E}$ cadherin sẽ không thực hiện được chức năng, gây ra rối loạn việc kết nối và truyền tín hiệu giữa các tế bào, làm tăng khả năng vận động của tế bào ung thư, dẫn đến tăng khả năng di căn. Việc hiểu rõ về cơ chế di truyên cũng như những biến đổi ở mức độ phân tử cung cấp những hiểu biết về cơ chế bệnh sinh, cũng như khả năng xác định những dấu ấn sinh học vầ các đích điều trị mới.

Chẩn đoán ung thư dạ dày sớm là một thách thức, vì triệu chứng lâm sàng thường xuất hiện muộn trong quá trình phát triển ung thư, cho nên việc nghiên cứu những yếu tố nguy cơ như đột biển gen $\mathrm{CDH} 1$ là điều cần thiết để phát hiện sớm bệnh và đưa ra một phác đồ điều trị phù hợp nhất cho bệnh nhân. Vì vậy nên nghiên cứu được thực hiện với mục tiêu: xác định đột biến gen $\mathrm{CDH} 1$ trền bệnh nhân ung thư dạ dày type lan toả bằng kỹ thuật giải trình tự gen.

\section{II. Đốl TƯợNG VÀ PHƯƠNG PHÁP NGHIÊN CỨU}

\section{1. Đối tượng nghiên cứu}

- 30 bệnh nhân, tuối dưới 40, được chẩn đoán xác định ung thư da dày type lan toả, dựa vào lâm sàng và kết quả giải phẩu bệnh tại bệnh viện Bạch Mai.

\section{Phương pháp}

2.1. Phương pháp thu thập mẫu: Phương pháp lấy mẫu thuận tiện, $3 \mathrm{ml}$ máu ngoại vi của bệnh nhân ung thư dạ dày type lan toả được thu thập trong ống chống đông EDTA.

\subsection{Phương pháp tách chiết DNA từ} máu ngoại vi:

- DNA tổng số được tách chiết từ máu toàn phần theo kit Promega (USA).

- Nồng độ và độ tinh sạch của mẫu DNA sau tách chiết được đo ở tỷ số A260/A280 đạt tiêu chuẩn, có thể thực hiện các bước thí nghiệm tiếp theo.

\subsection{Phương pháp khuếch đại gen CDH1} bằng kỹ thuật PCR

- Phản ứng PCR được sử dụng để khuếch đại toàn bộ 16 exon và vùng promoter của gen CDH1 với các cặp mồi đặc hiệu theo nghiên cứu của El-Husny và cộng sự (2016) [5].

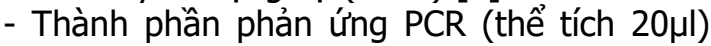
gồm 10X đệm Buffer, $10 \mathrm{mM}$ dNTP, $0.5 \mu \mathrm{l}$ mồi xuôi và mồi ngược, $5 U$ Taq polymerase, $3 \mu$ I DNA.

- Chu trình nhiêt của phản ứng PCR: $94^{\circ} \mathrm{C} / 5$ phút, 40 chu kỳ $\left[94^{\circ} \mathrm{C} / 30\right.$ giây, $58^{\circ} \mathrm{C} / 30$ giây, $72^{\circ} \mathrm{C} / 45$ giây], $72^{\circ} \mathrm{C} / 5$ phút. Bảo quản mẫu ở $10^{\circ} \mathrm{C}$.

2.4. Giái trinh tưr gen CDH1 bằng kỹ thuât giải trình tự trực tiếp Sanger. Các sản phẩm PCR sẽ được tiến hành giải trình tự trực 
tiếp trên máy ABI 3100 Genetic Analyzer. Kết quả được thu thập và xử lý bằng phân mềm CLC Main Workbench 6.0. Trình tự được so sánh với trình tự chuẩn trên ngân hàng gen: DNA (NG_008021) và mRNA (NM_004360)

3. Đạo đức trong nghiên cứu. Nghiên cứu tuân thủ chặt chẽ theo đạo đức nghiên cứu trong $Y$ học. Bệnh nhân hoàn toàn tự nguyện tham gia vào nghiên cứu và có quyên rút lui khỏi nghiên cứu khi không đồng ý tiếp tục tham gia. Các thông tin cá nhân, kết quả chẩn đoán hoàn toàn được đảm bảo bí mật.

\section{KẾT QUẢ NGHIÊN CứU}

\section{1. Đăc điểm nhóm nghiên cứu}

Bảng 1. Đặc điểm chung của nhóm nghiên cứu

\begin{tabular}{|c|c|c|c|}
\hline \multicolumn{2}{|c|}{ Đặc điểm } & n & \% \\
\hline \multirow{2}{*}{ Giới } & Nam & 18 & 60 \\
\cline { 2 - 4 } & Nữ & 12 & 40 \\
\hline \multicolumn{2}{|c|}{ Tuổi trung bình } & \multicolumn{2}{|c|}{34.93} \\
\hline \multicolumn{2}{|c|}{ Khoảng tuổi } & \multicolumn{2}{|c|}{$21-40$} \\
\hline
\end{tabular}

Trong số 30 bênh nhân ung thư da dày type lan toả, tỷ lệ nam chiếm $60 \%$, tuổi trung bình 34.93 (khoảng tuổi từ 21 đến 40).

\section{Kết quả khuếch đại vùng promoter và} các exon của gen CDH1

Sử dụng các cặp mồi đặc hiệu cho toàn bộ 16 exon và vùng promoter gen $\mathrm{CDH} 1$ để khuếch đại DNA sau tách chiết từ mẫu máu của bênh nhân. Kết quả PCR khuếch đại gen $\mathrm{CDH} 1$ đại diện của mẫu GC01 được minh hoạ ở hình 1.

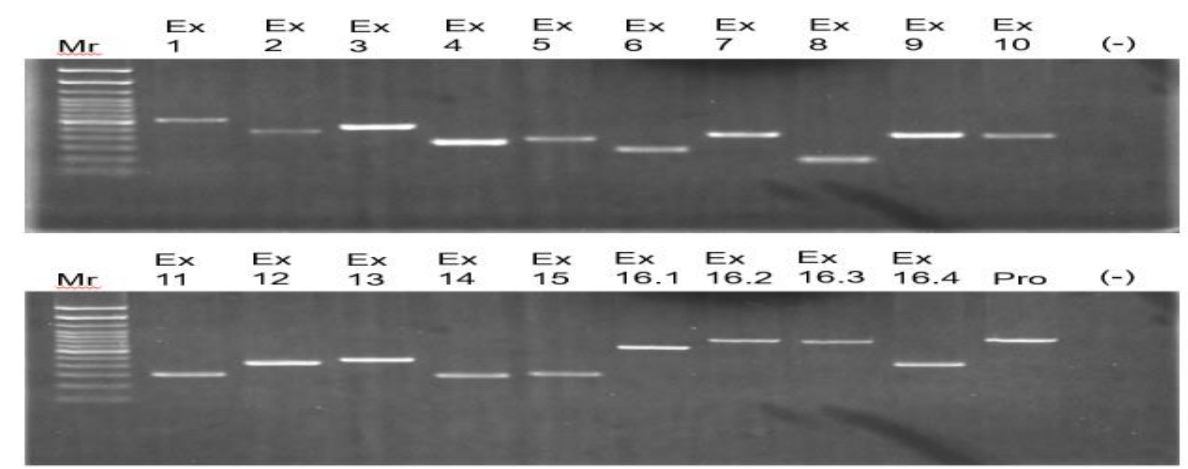

Hình 1. Hình ảnh điện di sản phẩm PCR khuếch đại 16 exon và vùng promoter gen CDH1 của bệnh nhân GC01. Mr: Marker 100bp, Ex: Exon, Pro: Promoter

Kết quả điện di trên gel agarose $1.5 \%$ cho thấy các vạch PCR duy nhất, rõ nét, kích thước đặc hiệu cho từng exon và vùng promoter của gen $\mathrm{CDH} 1$. Các sản phẩm PCR đảm bảo cho phản ứng giải trình tự tiếp theo để phát hiện đột biến.

3. Kết quả xác định đột biến gen CDH1. Sản phẩm PCR được giải trình tự gen trực tiếp để phát hiện đột biến. Kết quả xác định đột biến gen $\mathrm{CDH} 1$ trên bệnh nhân ung thư dạ dày biểu mô type lan toả được trình bày trong bảng 2 .

Bảng 2. Kêt quả đôt biến gen CDH1 trên bệnh nhân ung thư dạ dày

\begin{tabular}{|c|c|c|c|}
\hline Mã số & $\begin{array}{l}\text { Exon/ } \\
\text { Intron }\end{array}$ & Đột biến & $\begin{array}{l}\text { Thế } \\
\text { đột biến }\end{array}$ \\
\hline GC01 & Intron 1 & $c .48+6 \mathrm{C}>\mathrm{T}$ & Đồng hợp tử \\
\hline GC03 & Intron 1 & $c .48+6 C>T$ & Đồng hợp tử \\
\hline GC07 & Intron 1 & c. $48+6 \mathrm{C}>\mathrm{T}$ & Đồng hợp tử \\
\hline GC16 & Intron 1 & c. $48+6 \mathrm{C}>\mathrm{T}$ & Đông hợp tử \\
\hline GC25 & Intron 1 & c. $48+6 \mathrm{C}>\mathrm{T}$ & Đông hợp tử \\
\hline GC10 & Operator & c. $1-285 \mathrm{C}>\mathrm{A}$ & Đông hợp tử \\
\hline GC14 & Operator & c. $1-285 C>A$ & Đồng hợp tử \\
\hline GC27 & Operator & c. $1-285 \mathrm{C}>\mathrm{A}$ & Đồng hợp tử \\
\hline GC05 & Exon 8 & c.1248 delT & Đồng hợp tử \\
\hline
\end{tabular}

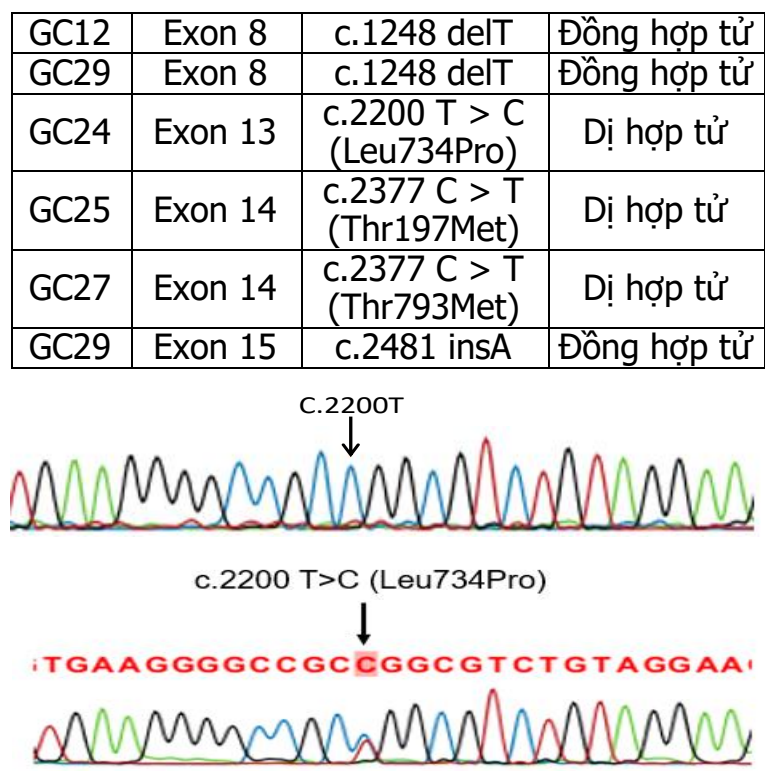

Hình 2. Kêt quả giải trinh tư gen CDH1 tại exon 13 C.2200 T>C (Leu734Pro)

Kết quả trên người khoẻ mạnh (hình trên); Kết quả trên bệnh nhân GC24 (hình dưới) 
Bảng 3. Tỷ lệ đột biến phát hiện được trên bệnh nhân ung thư dạ dày type lan toả

\begin{tabular}{|c|c|c|}
\hline Đột biến & Số lượng & Tỷ lệ \\
\hline Intron 1 c.48+6 C > T & $5 / 15$ & $33,3 \%$ \\
\hline Operator c.1-285 C > A & $3 / 15$ & $20 \%$ \\
\hline Exon 8 c.1248 del T & $3 / 15$ & $20 \%$ \\
\hline $\begin{array}{c}\text { Exon 13 c.2200 T > C } \\
\text { (Leu734Pro) }\end{array}$ & $1 / 15$ & $6,7 \%$ \\
\hline $\begin{array}{c}\text { Exon 14 c.2377 C > T } \\
\text { (Thr197Met) }\end{array}$ & $2 / 15$ & $13,3 \%$ \\
\hline Exon 15 c.2481 insA & $1 / 15$ & $6,7 \%$ \\
\hline
\end{tabular}

Kết quả cho thấy, phát hiện đột biến gen CDH1 ở 15/30 bệnh nhân ung thư dạ dày biểu mô type lan toả, chiếm $50 \%$. Các đột biến phổ biến nhất phát hiện được là đột biến tại vùng intron 1 c48+6 C> T, chiếm 33,3\% tổng số ca bệnh phát hiện đột biến; tiếp đến là đột biến tại operator $\mathrm{c} 1-285 \mathrm{C}>\mathrm{A}$ và đột biến tại exon 8 c.1248 delT, đều chiếm $20 \%$. Các kết quả giải trình tự được minh hoạ trong hình 2 và 3.

\section{BÀN LUẬN}

Chúng tôi lựa chọn 30 bệnh nhân được chẩn đoán là ung thư dạ dày type lan toả theo phân loại của Lauren (1956). Tuổi trung bình của nhóm nghiên cứu là 34.93 tuổi, độ tuổi dao động từ 21 đến 40 tuổi. Theo Choi (2018) nghiên cứu trên nhóm bệnh nhân ung thư da dày lan toả có độ tuổi trung bình là 52,55 tuổi [6]. Do bênh nhân ung thư dạ dày lan toả thường ở những bệnh nhân khởi phát sớm nên độ tuổi của bệnh nhân thường dưới 40 tuổi. Do đó, độ tuổi của nhóm bệnh nhân trong nghiên cứu của chúng tôi là phù hợp với các đặc điểm chung của bệnh nhân ung thư dạ dày lan toả. Tỷ lệ nam và nữ trong nghiên cứu của chúng tôi lần lượt là $60 \%$ và $40 \%$. Kết quả này của chúng tôi tương đồng với nghiên cứu của Choi (2018), với tỷ lệ bệnh nhân nam chiếm $60.87 \%$ [6].

Đến nay có khoảng hơn 100 loại đột biến gen $\mathrm{CDH} 1$ đã được phát hiện trên toàn thế giới [7]. Tỷ lệ các loại đột biến: chèn hoặc xoá đoạn nhỏ $35 \%$, thay thế $28 \%$, vô nghĩa $16 \%$, xoá đoạn lớn $5 \%$ [8]. Nhiều công bố gần đây cho thãy đột biến trên gen $\mathrm{CDH} 1$ không có vùng hotspot, đột biến xảy ra rải rác trên dọc chiều dài của gen $\mathrm{CDH} 1$ [7]. Các nghiên cứu trên thế giới cho thấy tần số đột biến dòng tế bào mầm gen $\mathrm{CDH} 1$ trong ung thư dạ dày lan toả có tỷ lệ dao động từ $3 \%$ đến trên $50 \%$ [8]. Kết quả nghiên cứu trên 30 bệnh nhân ung thư dạ dày lan toả, có 15 bệnh nhân có biến đổi trên gen $\mathrm{CDH} 1$, chiếm tỷ lệ $50 \%$. Trong đó, Các đột biến phổ biến nhất phát hiện được là đột biến tại vùng intron 1 c48+6 C > T, chiếm 33,3\% tổng số ca bệnh phát hiện đột biến; tiếp đến là đột biến tại

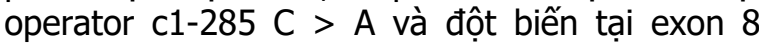
c. 1248 delT, đều chiếm $20 \%$.

Ngoài biến đổi ở vùng intron $1 \mathrm{c} 48+6 \mathrm{C}>\mathrm{T}$ đã được chỉ ra trong các nghiên cứu trước đây [9], các biến đổi khác trong nghiên cứu của chúng tôi chưa được công bố và sự liên quan đến ung thư dạ dày lan toả chưa rõ. Tuy nhiên, đột biến tại exon 8 c.1248 delT có thể gây ra các đột biến dịch khung, làm thay đổi trình tự acid amin, kết quả có thể tao ra protein E-cadherin không thực hiện được chức năng, ảnh hưởng đến hình thái và sự vận động của tế bào, sự sắp xếp lại khung xương tế bào, từ đó ảnh hưởng đến sự phát triển và di căn của tế bào ung thư'. Loại đột biến thay thế $T$ thành $C$ trên exon 13 đã được Xu Y và cộng sự phát hiện năm 2014, kết quả làm thay thế acid amin Leucine thành Proline, làm ảnh hưởng đến ái lực của protein Ecadherin với ion canxi.

Tỷ lệ đột biến trong nghiên cứu của chúng tôi là $50 \%$. Tỷ lệ này cao hơn so với nghiên cứu của Lee (2014) là 35,7\%. Có sự khác biệt trên là do trong nghiên cứu này, chúng tôi xác định đột biến trên toàn bộ chiêu dài gen $\mathrm{CDH} 1$, kể cả vùng promoter và có thể do nghiên cứu được tiến hành trên nhiều quốc gia khác nhau. Những kết quả trên cho thấy đột biến gen $\mathrm{CDH} 1$ có vai trò quan trọng, có thể sử dụng như một dấu ấn ung thư trong việc sàng lọc, chẩn đoán ung thư dạ dày lan toả, đặc biệt là trên những bệnh nhân trẻ tuổi.

\section{KẾT LUẬN}

Trong nghiên cứu này, 15/30 (50\%) bệnh nhân mang đột biến gen $\mathrm{CDH} 1$. Trong đó, đột biến phổ biến nhất là đột biến tại vùng intron 1 c48+6 C > T, chiếm 33,3\%; tiếp đến là đột biến tại operator $\mathrm{c} 1-285 \mathrm{C}>\mathrm{A}$ và đột biến tại exon 8 c.1248 delT, đều chiếm $20 \%$.

\section{TÀI LIÊU THAM KHẢO}

1. Siegel R.L., Miller K.D., và Jemal A. (2020), Cancer statistics, 2020. CA Cancer J Clin, 70(1), 7-30.

2. Rahman R., Asombang A.W., và Ibdah J.A. (2014). Characteristics of gastric cancer in Asia. World J Gastroenterol, 20(16), 4483-4490.

3. Ansari S., Gantuya B., Tuan V.P. và cộng sự. (2018). Diffuse Gastric Cancer: A Summary of Analogous Contributing Factors for Its Molecular Pathogenicity. Int J Mol Sci, 19(8).

4. Hansford S., Kaurah P., Li-Chang H. và cộng sự. (2015). Hereditary Diffuse Gastric Cancer Syndrome: $\mathrm{CDH} 1$ Mutations and Beyond. JAMA Oncol, 1(1), 23-32. 
5. El-Husny A., Raiol-Moraes M., Amador M. và cộng sự. (2016). CDH1 mutations in gastric cancer patients from northern Brazil identified by Next- Generation Sequencing (NGS). Genet Mol Biol, 39(2), 189-198.

6. Choi J.-H., Kim Y.-B., Ahn J.M. và cộng sự. (2018). Identification of genomic aberrations associated with lymph node metastasis in diffusetype gastric cancer. Exp Mol Med, 50(4), 1-11.

7. Camargo M.C., Goto Y., Zabaleta J. và cộng sư. (2012). Sex hormones, hormonal interventions, and gastric cancer risk: a meta- analysis. Cancer Epidemiol Biomark Prev Publ Am Assoc Cancer Res Cosponsored Am Soc Prev Oncol, 21(1), 20-38.

8. Oliveira C., Sousa S., Pinheiro H. và cộng sự. (2009). Quantification of epigenetic and genetic 2nd hits in $\mathrm{CDH} 1$ during hereditary diffuse gastric cancer syndrome progression. Gastroenterology, 136(7), 2137-2148.

9. Chen Q.-H., Deng W., Li $X_{\text {. }}-W$. và cộng sự. (2013). Novel $C D H 1$ germline mutations identified in Chinese gastric cancer patients. World J Gastroenterol WJG, 19(6), 909-916.

\section{NGHIÊN CỨU ĐĂC ĐIỂM TỔN THƯƠ'NG HẮC VÕNG MẠC QUANH ĐĨA THI TRÊN LÂM SÀNG VÀ CHIÊUU DÀY LỚP SỢI THẦN KINH QUANH ĐĨA THỊ TRÊN OCT Ở MẮT CÂ̂N THI CAO}

\section{TÓM TẮT}

Mục tiêu: Đánh giá đặc điểm tổn thương hắc võng mạc quanh đĩa thị trên lâm sàng, chiều dày của lớp sợi thần kinh quanh đĩa thi bằng OCT trên mắt cận thị cao và một số yếu tố liên quan. Đối tượng và phương pháp nghiên cứu: Nghiên cứu mổ tả cắt ngang trên 168 mắt của 88 bệnh nhân có mức độ cận thị $\leq-6.00 D$, tại khoa Khúc xạ - Bệnh viện Mắt Trung Ương. Kết quả: số mắt có tổn thương hắc võng mạc quanh đĩa thi là 118 mắt $(70,2 \%)$. Chiêu dày trung bình lớp sợi thần kinh quanh đĩa thị là $88,21 \pm 8,74$ $\mu \mathrm{m}$, trong đó chiều dày lớp sợi thần kinh quanh đĩa thị ở những trưởng hợp có tổn thương hắc võng mạc quanh đĩa thi $(86,39 \pm 8,04 \mu \mathrm{m})$ mỏng hơn so với những trường hợp không có tổn thương hắc võng mạc quanh đĩa thi $(92,52 \pm 8,92 \mu \mathrm{m})$, sự khác biệt có ý nghĩa thống kê $(p<0,01)$. Khi thời gian mắc cận thị càng lâu, mức độ cận càng cao và chiều dài trục nhãn cầu càng dài thì càng có nguy cơ tổn thương hẳc võng mạc quanh đĩa thị. Khi mức độ cận càng cao thì lớp sợi thân kinh quanh đĩa thị càng mỏng. Kết luận: Trên mắt cận thị cao, ba yếu tố: thời gian mắc cận thị, mức đô cận thí, và chiều dài trục nhãn câu có liên quan với tổn thương hắc võng mạc quanh đĩa thị. Chiều dày lớp sợi thần kinh quanh địa thi ở mắt có tổn thương hắc võng mạc quanh đĩa thị mỏng hơn ở mắt không có tổn thương. Yếu tố mức độ cận thị có liên quan với chiều dày lớp sợi thần kinh quanh đĩa thị.

\section{SUMMARY}

STUDYING CHARACTERISTIC OF CHOROIDAL RETINAL DAMAGE AROUND THE OPTICAL DISC IN CLINIC AND THE

${ }^{1}$ BV Mắt trung ương

Chịu trách nhiệm chính: Nguyễn Thị Thu Hiền

Email: Thuhienvnio@gmail.com

Ngày nhận bài: 18.2.2021

Ngày phản biên khoa hoc: 26.3.2021

Ngày duyệt bài: 7.4.2021
Nguyễn Thị Thu Hiền'1, Phạm Thị Minh Châu ${ }^{1}$

\section{NERVE FIBER LAYER THICKNESS AROUND} THE OPTICAL DISC BY OCT IN HIGH MYOPIA

Objective: To assess the characteristic of choroidal retinal damage around the optical disc in clinic, the nerve fiber layer thickness around the optical disc by OCT in high and risk factors. Methods: A cross-sectional study on 168 eyes of 88 patients with high myopia was conducted between January 2020 and August 2020 at the Refraction Department of Vietnam National Institute of Ophthalmology. Results: the number of eyes with choroidal retinal damage around the optical disc was 118 eyes $(70.2 \%)$. The average thickness of the nerve fiber layer around the optical disc was $88.21 \pm 8.74 \mu \mathrm{m}$, in which the thickness of the nerve fiber layer around the optic disc in the eyes with choroidal retinal damage around the optical disc $(86.39 \pm 8.04 \mu \mathrm{m})$ was thinner than this of the eyes without the damage $(92.52 \pm 8.92 \mu \mathrm{m})$, the difference was statistically significant $(p<0.01)$. The longer of myopia duration, the higher of myopia level, and the longer of axis length, the risk of choroidal retinal damage around the optical disc was higher. The higher of myopia level, the thickness of the nerve fiber layer around the optic disc was thinner. Conclusions: In high myopic eyes, three factors: the duration of myopia, the degree of myopia, and the axis length were associated with choroidal retinal damage around the optical disc. The thickness of the nerve fiber layer around the optic disc in the eyes with choroidal retinal damage around the optical disc was thinner than this of the eyes without the damage. Myopic level factors are associated with the thickness of the nerve fiber layer around the optical disc.

\section{I. ĐẶT VẤN ĐỀ}

Cân thị, đặc biệt cận thị cao là tật khúc xa phổ biến hiện nay, gây ảnh hưởng chủ yếu đến thị lực nhìn xa, làm suy giảm chất lượng cuộc sống đồng thời gây ra gánh nặng kinh tế đáng 